\title{
Content Analysis of Official Twitter Account of Under-20 Football World Cup
}

\author{
Levent Atali' ${ }^{1}$, Burak Gürer ${ }^{2}$ \\ ${ }^{1}$ School of Physical Education and Sports, Kocaeli University, Kocaeli, Turkey \\ ${ }^{2}$ School of Physical Education and Sports, Batman University, Batman, Turkey \\ Email: leventatali@gmail.com
}

Received 1 April 2015; accepted 21 April 2015; published 23 April 2015

Copyright (C 2015 by authors and Scientific Research Publishing Inc.

This work is licensed under the Creative Commons Attribution International License (CC BY). http://creativecommons.org/licenses/by/4.0/

(c) (i) Open Access

\section{Abstract}

The aim of this study is to examine the content of use of the official Twitter account of the FIFA U-20 World Cup during the period of the organization. It has been sought answers to the questions "What is the intensity of use of the official Twitter account of the FIFA U-20 World Cup?" and "What are the contents of tweets posted via official Twitter account of the FIFA U-20 World Cup?" for this purpose. The official Twitter account of the FIFA U-20 Football World Cup held in Turkey in 2014 was examined and a total of 4558 Tweet content posted via official Tweet account were determined. The frequency distribution was used for the analysis of the data obtained. It was found that the official Twitter account of the FIFA U-20 Football World Cup followed 213 people and had 7494 followers. It was found that $\mathbf{4 5 5 8}$ Tweets were posted via the official Twitter account and seen that "overall organization information" with 1558 tweets was in the first place among the contents and respectively, 829 tweets with the content of "match summary", 672 tweets as "re-tweets", 629 tweets with the content of "photo", 456 tweets with the content of "match review", 279 tweets about "personal descriptions about athletes and coaches", 108 tweets "about the football matches" and 30 tweets about "TV programs" followed it when sorted. Although the number of followers was 7494, the number of those who posted tweets was only 168 and this state shows that those who follows the cup prefer to remain as audience. In conclusion, we saw that the official Twitter account of the U-20 Football World Cup has been subject to a one-way flow, mostly. We can say that a re-planning which will ensure an active participation of followers would be more useful.

\section{Keywords}

Social Media, Twitter, Football, World Cup

\section{Introduction}

Internet based changes and innovations like social media brought by technological developments in recent years 
have created some changes and effects. Such changes and effects have changed manufacturing and marketing activities, sales strategies, and competition techniques of enterprise as well as relevant instruments used by these enterprises (Ünal, 2011). A giant social sharing platform with an unprecedented scale and easiness has come into our life with social media (Kahraman, 2010). Blossom (2010) defined social media as a highly scalable and accessible communications technology or technique that enables any individual to influence groups of other individuals easily.

The basic reason for using social media is that it interconnects individuals. Social media also enables enterprises to communicate, cooperate and share important knowledge necessary for performing their tasks in a better and quick manner (Jue, Alcalde, \& Kassostakis, 2010). Besides these reasons, consumers use social media for its several advantages. Social media enables several sports supporters to communicate through these advantages (Aşman \& Kilıç, 2011). Fouts (2009) mentioned that there are several ways of busy oneself in social media and that many social media instruments have been developed for this purpose. Social media application named "twitter" is one of these media instruments.

Social media instruments like Facebook, Twitter and blogging sites have become efficient in sports field like other fields of life. Particularly Facebook and Twitter activates the communication between athletes, sports clubs and supporters. Athletes now use social media for knowledge sharing (Çavuşoğlu, Öztürk, \& Kara, 2011). Sports supporters desire to have higher quality photographs and knowledge with never-before-seen speed. Sports supporters also want to acquire sport-related information and other elements from different sources. New technology provides this opportunity by establishing direct communication for supporters (Atal1, 2003). Hall et al. (2007) sport organizations and supporters will always have to develop new effective communication techniques, and computers will play the vital role.

Social media instruments are an efficient way of communication for athletes, coaches, teams, and leagues that increases its importance gradually. Argan and Katırc1 (2002) stated that sport marketing has changed its form by new technologies, and supporters have become more interactive. The importance of internet has increased since sport became a global product; and internet use in sports field has also increased.

As internet use became widespread in sports field, communication has become easier and tribunes were influenced by new communication ways. That supporters are informed about their own tribunes as well as other tribunes shows that internet is used extensively in providing effective participation in organizations (Hatipoğlu \& Aydin, 2007).

Sport industry has opened its doors to innovation by using recent technologies. Expectations of athletes and supporters today cause technology and sport to become interlocked (Devecioğlu \& Altıngül, 2011). New technologies have increased the number of supporters in social media and created a new supporter group. In this context, new technologies have an important effect on sports (Rein \& Kotler, 2006). The effect of social media and social media instruments on increasing the number of supporters has reached a challenging size.

\section{Aim of the Study}

The aim of this study is to examine the content of use of the official Twitter account of the FIFA U-20 World Cup during the period of the organization. It has been sought answers to the questions "What is the intensity of use of the official Twitter account of the FIFA U-20 World Cup?" and "What are the contents of tweets posted via official Twitter account of the FIFA U-20 World Cup?” for this purpose.

\section{Method}

The method used in the study is the content analysis that is one of the qualitative research methods. Content analysis is the type of analysis that is used to measure variables in a text systematically, objectively and quantitatively (Wimmer \& Dominick, 2000). The state that exists in this study was examined impartially.

The content of use of the official Twitter account of the FIFA U-20 World Cup during the period of the organization constitutes the field of use. Tweet accounts of 7494 people following the official Tweeter account of the organization during the organization and 4558 Tweet content posted via official Tweet account were examined. Data obtained by content analysis within the scope of the study were analyzed by using descriptive statistical methods [percentage and frequency].

\section{Findings}

As the result of the examination of Table 1, it was found that organization posted 4558 tweets and the account 
of the organization follows 213 people and the Twitter account of the organization was followed by 7494 people.

As the result of the examination of Tweeter contents in Table 2, it was found that "overall organization information" with 1558 tweets took the lead and then "match summary" with 829 tweets, "retweet" with 672 tweets, "photo" wit 629 tweets, "match review" with 456 tweets, "personal descriptions about athletes and coaches" with 279 tweets, "about the football matches" with 180 tweets and "TV programs" with 30 tweets were ranged respectively.

As the result of the examination of Table 3, the number of people posted Tweets out of the followers of the organization's official account was found 168 and number of Tweets posted by them was found 659 .

\section{Discussion and Result}

The content of use of the official Twitter account of the FIFA U-20 World Cup during the period of the organization was examined by this study and it has been sought answers to the questions "What is the intensity of use of the official Twitter account of the FIFA U-20 World Cup?" and "What are the contents of tweets posted via official Twitter account of the FIFA U-20 World Cup?” for this purpose.

Football is one of the world's most popular sports with its simple rules and easy access to the equipments required for to play football (Orazio \& Leo, 2010). Even the smallest detail to develop football in the developing world is being shed light on and various studies are being conducted to increase the game speed, ratio of goals and make football a game pleasing to the eye (Kanat, 2007). Posted 4558 tweets within the scope of the study and number of people posted tweet during the organization was only 168 people may be interpreted as the fact

Table 1. Twitter account.

\begin{tabular}{cc}
\hline & f \\
\hline Tweets & 4558 \\
Followed (U20 Org.) & 213 \\
Followers (person) & 7494 \\
\hline
\end{tabular}

$f=$ frekans.

Table 2. Tweet contents of the U20 Organization.

\begin{tabular}{ccc}
\hline & $\mathrm{f}$ & $\%$ \\
\hline Overall organization information & 1558 & 34.18 \\
Match summary & 829 & 18.18 \\
Retweet & 672 & 14.74 \\
Photo & 629 & 13.79 \\
Match review & 456 & 10.00 \\
Personal descriptions about athletes and coaches & 276 & 6.05 \\
About the football matches & 108 & 2.36 \\
TV Programs [organization] & 30 & 0.65 \\
TOTAL & 4558 & 100 \\
\hline
\end{tabular}

$f=$ frekans

Table 3. Twitter statistics of followers.

\begin{tabular}{ccc}
\hline & $\mathrm{f}$ \\
\hline Number of people posted tweets & 168 \\
Number of total tweets posted & 659 \\
\hline
\end{tabular}

$\mathrm{f}=$ frekans 
that the interest on the organization was not so much when considering the football audience in Turkey. The results of the study show that Under-20 Football World Cup seems to have not drawn the interest of so many followers.

Thus, the study to refer to a different point in terms of football is important. Under-20 Football World Cup did not attract the attention of football audience in Turkey. The insufficient level of promotion or of the interest of supporter group to a media such as Twitter may be shown as a cause to that fact. It can be concluded that the lack of football players known throughout the world may have negatively affected the Under-20 Football World Cup and thus, influenced the tweets posted accordingly. Posted 1558 tweets related to the organization make us think that athletes were not followed so much. That only 276 tweets posted related to football players shows that young athletes are being followed less than expected.

In conclusion, Under-20 Football World Cup has become an organization during which many tweets were posted in issues such as match reviews, personal descriptions about athletes and coaches and about the football matches and TV programs. Many researches were conducted in the field of football in the last ten years in order to perfect the techniques and make them consistent and reliable and to develop valid methods. Especially the researches to be conducted for young athletes are important in order to draw their attention to that sports branch at a young age.

Better promotions and introductions are required especially to create and draw attention to the organizations where young players take place and diversification of studies and researches related to the organizations where young players take place will be important for the development of football.

\section{References}

Argan, M., \& Katırcı, H. (2002). Sports Marketing. Ankara: Nobel Yayınları.

Aşman, Ö., \& Kılıç, A. (2011). Public Relations 2.0 New Sharers, New Technics in Social Media. Ankara: Elif Yayınevi.

Atal1, L. (2013). Facebook Usage of Turkish Football Federation Spor Toto Super League Sports Clubs and Their Fans. Doctoral Thesis, Bolu: Abant İzzet Baysal University, Graduate School of Social Sciences.

Blossom, J., Content Nation. (2010). Surviving and Thriving as Social Media Changes Our Work, Our Lives, and Our Future. http://www.contentnation.com

Çavuşoğlu, B., Öztürk, G., \& Kara, B. (2011). The Strategic Importance of Internet Usage as New Media Tool in the Studies of Sports Marketing: Analysis of Sports Clubs' Websites in Turkey and England. The International Journal of Human Sciences, 8, 1343-1363.

Devecioğlu, S., \& Altıngül, O. (2011). Innovation in Sports Technologies. 6th International Advanced Technologies Symposium [IATS’11], 16-18 May 2011, Elazı̆̆.

Fouts, J. (2009). Social Media Success! Practical Advice an Dreal World Examples for Social Media Engagement. California: HappyAbout.info.

Hall, A., Nichols, W., Moynahan, P., \& Taylor, J. (2007). Media Relations in Sport. Morgantown: FIT.

Hatipoğlu, D., \& Aydın, B. (2007). Push Ankaragücü: City, Identity, Industrial Football and Fun. Ankara: Epos Yayınları, 270.

Jue, A., Alcalde, J., \& Kassostakis, M. (2010). Social Media at Work. San Francisco: Jossey-Bass.

Kahraman, M. (2010). Social Media, Introduction to Social Media for Marketting Experts. İstanbul: Mediacat Yayınları.

Kanat, Ş. Y. (2007). The Effects of the Maximal Strength Training Exercised on the Muscle of Upper Extremite on the Throw in Distance in Soccer. Ankara: Graduate School of Health Sciences, Gazi University, Yüksek Lisans Tezi.

Orazio, T. D., \& Leo, M. (2010). A Review of Vision-Based Systems for Soccer Video Analysis. Pattern Recognition, 43, 2911-2926.

Rein, I., \& Kotler, P. (2006). Here Supporter Is, Here Marketing Is. İstanbul: Medicat Yayınları.

Ünal, S. (2011). Customer Relations and Information Technologies in New Economy. İstanbul: Beta Yayınları.

Wimmer, D. D., \& Dominick, J. R. (2000). Mass Media Research: An Indroduction. Belmont: Wadsworth Publishing Company. 